\title{
The Reform of the Indonesian Competition Law to Anticipate ASEAN Economic Community
}

\author{
Ari Siswanto* and Marihot Janpieter Hutajulu** \\ DOI: https://doi.org/10.22304/pjih.v5n2.a3
}

Submitted: April 9, 2018 | Accepted: August 31, 2018

\begin{abstract}
This paper discusses the need to reform the Indonesian Competition Law (the Law Number 5 of 1999) due to the implementation of the ASEAN Economic Community (AEC), which undoubtedly influences the business condition in Indonesia. This study is expected to provide input for the revision of the Law Number 5 of 1999 by identifying the weaknesses of the current law. Accordingly, this paper aims to analyze the aspects of Indonesian Competition Law that are need to be reformed to ensure its capability in anticipating and regulating business competition after the implementation of AEC. This study found that the degree of the implementation of the Indonesian Competition Law is particularly specified in Article 1(e), which elucidates that the business actors to which the competition law applies are those who are "didirikan dan berkedudukan dalam wilayah hukum Republik Indonesia" (established and domiciled within the jurisdiction of the Republic of Indonesia) or "melakukan kegiatan dalam wilayah hukum negara Republik Indonesia" (to conduct activities within the territory of the Republic of Indonesia). The phrase "dalam wilayah hukum Republik Indonesia" (within the jurisdiction of the Republic of Indonesia) contained in Article 1(e) clearly indicates that the application of Indonesian Competition Law still relies heavily on the principle of territoriality. Therefore, the Indonesian Competition Law cannot reach business actors who are established, or are domiciled, or do conduct activities outside Indonesia, although they perform actions that affect the condition of business competition in Indonesia. Therefore, the Indonesian Competition Law needs to be reformed to enable its extra-territorial implementation based on the "effects doctrine" justifying the application of national law to any foreign business actors that causes the disruption of fair business competition conditions at the domestic level.
\end{abstract}

Keywords: ASEAN Economic Community, competition law, effects doctrine.

\section{Perubahan Hukum Persaingan Usaha Indonesia dalam Mengantisipasi Masyarakat Ekonomi ASEAN}

\begin{abstract}
Abstrak
Tulisan ini membahas tentang perlunya reformasi dalam Hukum Persaingan usaha Indonesia (UU No. 5 tahun 1999) berkenaan dengan pemberlakuan Masyarakat Ekonomi ASEAN (MEA) yang niscaya mempengaruhi kondisi persaingan usaha di Indonesia. Kajian ini diharapkan bisa memberikan masukan bagi upaya merevisi UU No. 5 Tahun 1999 dengan

\section{PADJADJARAN Journal of Law Volume 5 Number 2 Year 2018 [ISSN 2460-1543] [e-ISSN 2442-9325]}

Lecturer in Faculty of Law, Universitas Kristen Satya Wacana, Jl. Diponegoro 52-60 Salatiga 50711, arie. siswanto@staff.uksw.edu, S.H. (Universitas Dipenogoro), M.Hum. (Universitas Gadjah Mada).

** Lecturer in Faculty of Law, Universitas Kristen Satya Wacana, Jl. Diponegoro 52-60 Salatiga 50711, marihotjanpieter@gmail.com, S.H. (Universitas Gadjah Mada), M.Hum. (Universitas Dipenogoro), Dr. (Universitas Padjadjaran).
\end{abstract}


cara mengidentifikasi kelemahan-kelemahan yang ada di dalam Hukum Persaingan Usaha Indonesia dan perlu diperbaiki agar bisa mengantisipasi dan mengatur persaingan usaha yang dimunculkan oleh MEA. Studi ini mengemukakan bahwa cakupan keberlakuan Hukum Persaingan Usaha Indonesia terutama ditentukan dalam Pasal 1(e) UU No. 5 Tahun 1999 yang menjelaskan bahwa pelaku usaha yang dimaksud adalah pelaku usaha yang "didirikan dan berkedudukan dalam wilayah hukum Republik Indonesia" atau "melakukan kegiatan dalam wilayah hukum negara Republik Indonesia." Frasa "dalam wilayah hukum Republik Indonesia" yang ada dalam Pasal 1(e) tersebut secara jelas menunjukkan bahwa penerapan Hukum Persaingan Usaha Indonesia masih sangat bergantung pada prinsip teritorialitas. Dengan begitu, Hukum Persaingan Usaha Indonesia tidak bisa menjangkau pelaku usaha yang didirikan di luar Indonesia, berkedudukan di luar Indonesia dan melakukan kegiatan di luar Indonesia, meski pelaku usaha itu melakukan tindakan yang berdampak pada kondisi persaingan usaha di Indonesia. Oleh sebab itu, Hukum Persaingan usaha Indonesia harus diperbaiki sedemikian rupa sehingga memungkinkan diterapkannya "doktrin efek" yang membenarkan penerapan hukum nasional terhadap pelaku usaha asing yang mengganggu kondisi persaingan sehat pada aras domestik.

Kata kunci: doktrin efek, hukum persaingan usaha, Masyarakat Ekonomi ASEAN.

\section{A. Introduction}

In 2015, ASEAN members agreed the implementation of the ASEAN Economic Community (AEC). In fact, the idea of AEC was not a new idea. It is a part of the efforts to create ASEAN as a liberalized region through several regional economic and trade agreements, started from the 1990s. To establish the AEC, ASEAN members are committed to leverage existing economic agreements within the region, such as the Agreement on the Common Effective Preferential Tariff Scheme for ASEAN Free Trade Area (CEPT-AFTA), the ASEAN Trade in Goods Agreement (ATIGA), ASEAN Framework Agreement on Services (AFAS), and the ASEAN Comprehensive Investment Agreement (ACIA). The CEPT-AFTA and the ATIGA agreements primarily regulate the establishment of an ASEAN free goods trade zone, while AFAS regulates free trade in services. The ACIA, as a framework of cooperation, facilitates the flowing freedom of investment in the ASEAN region.

The liberalization of AEC subsequently makes ASEAN region a free trade area. It is marked, among others, by the increasingly dynamic mobility of business actors across national borders. The ease of investment activities enables foreign business actors to engage in commercial interaction with domestic business actors more intensely. Under such circumstances, legal instruments, especially in business competition, are required to respond to the possibility of emerging business competition that confront domestic business actors to foreign parties. In addition, strong and harmonized business laws and policies among ASEAN members also are needed to encourage the acceleration of ASEAN into a united market and production base. The ASEAN members are fully aware of these requirements. Therefore, the regional organization also has issued guidance of business competition in the form 
of a document entitled the ASEAN Regional Guidelines on Competition Policy (ASEAN Competition Guidelines). The Guidelines does not bind legally. The principles of competition policy contained in the ASEAN Competition Guidelines are expected to be adopted by ASEAN members. Nevertheless, the harmonization of competition laws among ASEAN members can be better to realize the ASEAN competitive single market. Based on the description, this paper focuses on the following two questions.

1. Does Indonesian competition law already contain adequate provisions to anticipate and to regulate foreign business actors, especially from fellow ASEAN members, who step into the domain of Indonesian business competition in the era of AEC?

2. Has the Indonesian competition law already complied with the ASEAN regional business competition principles that are set forth in the ASEAN Competition Guidelines?

Prior to the discussion of the two issues, this paper begins with a general description of the AEC and its characteristics, as well as the ASEAN principles of competition policy contained in the ASEAN Competition Guidelines. Subsequently, the first issue will be discussed by contemplating the Indonesian business competition law, particularly the regulation of foreign business actors and extraterritorial competition law enforcement. The discussion of the second issue will be followed by the focus on the compliance of Indonesian competition law compared to the ASEAN principles of competition policy that are contained in the ASEAN Competition Guidelines.

\section{B. The Formulation of the Principles of ASEAN Competition Guidelines}

The idea of establishing the AEC has developed as a part of the ideas to form the ASEAN Community. Formally, it was initiated in the Declaration of ASEAN Concord II in Bali on October 7, 2003. According to the declaration, ASEAN members envision that the ASEAN Community will be realized by 2020. In 2007, the $12^{\text {th }}$ ASEAN Summit in Cebu, Philippines, ASEAN members agreed a commitment to accelerate the establishment of ASEAN Community, including AEC, which would come into effect in 2015.

On November 20, 2007, the Heads of ASEAN states pronounced the AEC Blueprint. According to the document's consideration, the AEC Blueprint is intended to minimize development gaps among ASEAN members and to accelerate the implementation of AEC by 2015 through a system that heavily relies on regulations (rule-based system). Referring to the document, there are four main characteristics in the formation of AEC:

(1) a single market and production base;

(2) a highly competitive economic region;

(3) a region of equitable economic development; and

(4) a region that is fully integrated into the global economy. 
Then, these four main characteristics are broken down into more specific elements. The characteristics of the AEC as a very competitive economic area are to be realized by enhancing the regional economic competitiveness. Increasing competitiveness in the context of the AEC further is pursued through the aspects of business competition policy, consumer welfare ${ }^{1}$, Intellectual Property Rights, infrastructure development, taxation, and e-commerce.

Among these aspects, the aspect that is particularly relevant to this paper is competition policy. The main objective of business competition policy is to create a vigorous competition culture, such as the one developed in China. ${ }^{2}$ For that purpose, ASEAN members are expected to have adequate competition policy (including law), institutions, and arrangements. In order to establish the competition policy, institutions and arrangements that supports the AEC, ASEAN members agreed to encourage cooperation among ASEAN competition authorities, as well as to develop regional guidance on competition policy based on international best practices.

According to the existing data, the involvement of business actors among the ASEAN members in the form of foreign direct investment (FDI) shows substantial increase after 2010 (US\$16,306 million) until 2016 (US\$24,000 million). ${ }^{3}$ These data suggest that cross-border business activities among ASEAN members have been increasing even before the AEC is formally enacted by the end of 2015. This has been the case because the AEC also relies on existing ASEAN agreement instruments enacted even before the AEC was formally introduced, in particular the CEPT-AFTA. The growth trend of cross-border business activities among ASEAN members indicates that the volume of interaction among business actors of ASEAN members is increasing, and so is the interaction between local and foreign business. Increasing interaction among business actors will in turn also increase competition among local business actors with foreign business actors in the ASEAN region. This is what makes the business competition issue highly relevant in the context of the AEC.

ASEAN members are fully aware that the AEC will fundamentally bring changes to their business competition characteristics. Therefore, ASEAN members formulate an action plan in the field of business competition, titled the ASEAN Competition Action Plan 2016-2025 (ACAP 2016-2025), which contains the objectives and direction of business competition policy in ASEAN within ten years.

The document clearly defines that there are five strategic goals to be achieved. First, effective competition regimes are established in all ASEAN members. Second, the capacities of competition-related agencies in AMS are strengthened to effectively implement competition policy and law. Third, regional cooperation arrangements on competition policy and law are in place. Fourth, ASEAN members foster a competition-aware ASEAN region. Fifth, the last, ASEAN members move towards greater harmonization of competition policy and law in the region.

Richard Wish and David Bailey, Competition Law, Oxford: Oxford University Press, 2012, p. 1.

Daniel Zimmer (ed.), The Goals of Competition Law, Cheltenham: Edward Elgar Publishing Limited, 2012, pp. 379-397.

3 ASEAN, Celebrating ASEAN: 50 Years of Evolution and Progress, Jakarta: ASEAN Secretariat, 2017, p. 27. 
Previously, in 2010, ASEAN had issued a guidelines of business competition policy for its member countries in a document entitled ASEAN Regional Guidelines on Competition Policy (ASEAN Competition Guidelines). The guidelines were introduced to anticipate the establishment of a single ASEAN market, which is expected to be highly competitive and integrated to the global economy. The guidelines are compiled by the ASEAN Expert Group on Competition (AEGC), which later also is given the responsibility to observe the implementation of ACAP 20162025. However, the ASEAN Competition Guidelines also asserted that the document is only guidelines; and it does not have binding power over ASEAN members. ${ }^{4}$

ASEAN Competition Guidelines contains important aspects that should be considered as guidance by ASEAN members in the implementation of business competition policy within the region. It contains several aspects related to business competition, ranging from legal and business competition law significance, the scope of business competition law, business competition authority, business competition law, to inter-state cooperation in the field of business competition.

Although it lacks of legally binding character, the ASEAN Competition Guidelines is important in view of the fact that it contains the general principles that will accelerate the realization of harmonization of business competition law after the adoption by ASEAN members. In turn, the characteristics of ASEAN as a highly competitive market also will be strengthened. For that reason, some of the principles contained in the ASEAN Competition Guidelines is presented in this paper as benchmarks to measure the suitability of Indonesian competition law with the principles. The relevant principles are as follows: ${ }^{5}$

Competition policy (including competition law) should be a common instrument governing all business sectors and all business actors involved in commercial economic activities.

1. Competition policy should also apply to Government-Owned Enterprises, as long as there is no explicit exception by law.

2. Competition policy and law should be applied to legal entities and its scope should be extended to include individuals authorizing, engaging, or facilitating practices that are prohibited by competition policy and law.

3. Competition policy shall prohibit vertical as well as horizontal agreements between business actors that are preventing, distorting, or limiting business competition.

4. Competition policy should make space for the implementation of "hardcore restriction" for actions that must give negative impacts on business competition.

5. Competition policy also should enable the adoption of a "rule of reason" approach to assess actions that is not necessarily categorized as actions that negatively affect business competition.

6. Prohibition of anticompetitive agreements by competition law and policy also

\footnotetext{
ASEAN, ASEAN Regional Guidelines on Competition Policy, Jakarta: ASEAN Secretariat, 2010, p. 1. Ibid., pp. 6-12.
} 
must include trade decisions made by business associations.

7. Competition policy and law should prohibit concerted action, which covers any action taken under implicit coordination or understanding among business actors, but not yet at the stage where an agreement is made explicitly.

8. Abuse of dominant position must be prohibited.

9. Merger of companies that reduce competition substantially or interfere competition are prohibited.

10.Competition policy and law need to be supplemented by procedures that enable competition authority to evaluate mergers so that they do not violate competition rules.

11.The implementation of competition policy and law should not prevent a state from realizing other justifiable objectives that may deviate from the principles of business competition.

As mentioned before, these principles will serve as benchmarks to review the contents of the Indonesian competition law to determine the compatibility of Indonesian competition law to the principles.

\section{Indonesian Competition Law Regulation on Foreign Business Actors}

The Indonesian competition law was established in 1999. Its full title is the Law Number 5 of 1999 on Prohibition of Monopoly and Unfair Business Competition (Indonesian Competition Law). The emergence of the Indonesian Competition Law has particular significance. Previously, the legal norms of Indonesian business competition are not comprehensive and are still scattered in various laws.

The Indonesian Competition Law is established based on several reasons. The reasons are reflected in the consideration of the law. Similar with other countries, the main reason behind the formulation of the Indonesian Competition Law is the interest to establish a robust and fair competition climate, as well as to prevent the concentration of economic power on certain business actors. In addition, another reason for the establishment of the Indonesian Competition Law is to develop an economic democracy where everyone has equal opportunity in the production and distribution of goods and services. The situation is expected to boost economic growth through efficient market economy with the support of a robust business climate.

As previously mentioned, in the context of establishing a single ASEAN market, there are two interesting aspects to be discussed: (1) the aspects that are related to the preparedness of the Indonesian Competition Law to anticipate the emergence of foreign business actors from ASEAN members within the scope of Indonesian business competition; and (2) the aspects that are related to the compatibility of Indonesian competition law to the principles of ASEAN business competition contained in the ASEAN Competition Guidelines.

A careful observation can reveal the norms of business competition law in Indonesia, whether based on behavioral or structural approach. In essence, it 
targets the so called "business actors". Article 1(e) of the Indonesian Competition Law defines it as any individual or business entity, whether in the form of legal entity or non-legal entity, established and domiciled, or conducting activities, within the jurisdiction of the Republic of Indonesia, who conducts various business activities in the field of economy, either alone or jointly through agreements. Based on the definition, it can be concluded that the business actors who are the subjects of the Indonesian Competition Law could be an individual or a business entity, in the form of a legal entity or not a legal entity, and that is established and domiciled, or conducting activities, within the territory of the Republic of Indonesia.

The phrase "established and domiciled, or conducting activities, within the territory of the Republic of Indonesia" brings important implications for the implementation of Indonesian competition law. It includes the context of the AEC, the subject of this paper. The words "established and domiciled" indicate any business actor to whom the rules of the Indonesian Competition Law bind as the legal subject. It means that all business, whether owned by Indonesian citizen or by foreigner, are subjects to Indonesian Competition Law as long as the business are established and domiciled within the territory of the Republic of Indonesia. Therefore, based on this principle, territoriality is the main principle in determining subjects to whom the Indonesian Competition Law binds.

Another part of the phrase, "conducting activities within the territory of the Republic of Indonesia", also has significance for the implementation of the Indonesian Competition Law. The basis of the Law's implementation lies on the principle of territoriality. Based on this principle, the Indonesian Competition Law can be valid for any business actor, including foreign business actor, as long as the business actor is engaged in business activities in the territory of Indonesia. based on Article 1(e) of the Indonesian Competition Law, territoriality is the foremost principle to be considered in the implementation of the law.

In addition to the implementation basis that is inferred from the definition of business actors, the enforcement of the Indonesian Competition Law against foreign business actors also has another basis. It is Article 16 of the Indonesian Competition Law, which states "Business actors are prohibited to enter into agreements with other parties abroad that contain provisions that may result in the practice of monopoly and/or unfair business competition". This provision allows the norms of the Indonesian Competition Law to prohibit business actors as defined in Article 1(e) from entering agreements with foreign parties abroad. Indirectly, this provision implicitly limits the opportunity of business actors outside Indonesia to enter an agreement with a business actor in Indonesia, if the substance of the agreement may result in monopolistic practices and or unfair business competition. 
However, Article 16 of the Indonesian Competition Law seems to target business actors that fall under the category of Article 1(e). It regulates the actors to have territorial relationship with Indonesia in terms of their establishment, domicile, or business activities.

Based on this interpretation, territoriality is a major factor in the determination of the normative implementation of Indonesian Competition Law, since it provides an explanation that Indonesian Competition Law is valid for persons or entities establish and domicile in Indonesia, as well as persons or business entities that conduct activities within the territory of Indonesia. Both situations use territory as the starting point of the implementation of Indonesian Competition Law. In the ASEAN single market era, this provision still can be used to apply legal norms of business competition on foreign business actors from ASEAN members as long as they run business activities in Indonesia.

Conversely, more complicated issues may likely arise in situations involving extraterritorial dimensions. For example, some foreign business actors operating outside Indonesia agree on a cartel agreement among themselves; and the cartel agreement involving those foreign business actors abroad bring impacts on the Indonesian market as their export destination. Business actors in Indonesia can experience the actual damage but there is no clarity as to whether the Indonesian competition law can reach the foreign business actors. The logic of Article 1(e) and Article 6 of the Indonesian Competition Law makes the Law unable to reach the foreign business actors involved in cartel agreement abroad. The reason is clear that the business actors do not establish, or domicile, in the territory of Indonesia. The law also cannot reach business actors having agreement with Indonesian business actors. Therefore, Article 6 is irrelevant. The only possible connecting factor between those business actors and the territory of Indonesia is the issue whether they conduct their business in the territory of Indonesia or not. However, the law does not concern the definition of the phrase "conducting activities within the territory of the Republic of Indonesia" mentioned in Article 1(e). An extensive interpretation probably could include the act of selling products in Indonesian market as "conducting activities within Indonesia". Still, the notion is a version of interpretation, not a clear legal definition.

Competition situations that involve extra-territorial dimensions such as shown by the above example are likely to become more frequent as the global economy develops. The actions of business actors in a country may have serious impacts elsewhere. Under these conditions, effective regulation cannot be realized simply by relying on the rigid application of the territorial principle. Thus, the extra-territorial reach of national competition law and what Dabbah termed as "internationalization" of competition policy become inevitably important. ${ }^{6}$

\footnotetext{
Maher M. Dabbah, The Internationalization of Antitrust Policy, Cambridge: Cambridge University Press, 2003, p. 4.
} 
In fact, the problem of extra-territoriality in competition law is faced by many countries in this globalized world. The core problem posed in this context is the fact that while the situation that will be addressed is globalization (which create extraterritoriality issues), the laws that are applied to global markets are not themselves global-or even transnational. Rather, the situation is that the laws of individual states govern global markets. ${ }^{7}$ The need for extra-territorial application of domestic laws in terms of competition issues is also raised by Klein. According to Klein, effective antitrust enforcement in today's global economy depends on three factors. One of them is the "extraterritorial" implementation of a country's laws. ${ }^{8}$

The extra-territoriality issue and the adjacent problems are related closely to traditional principles in international law. Public international law has long recognized territory as the main base of jurisdiction. A state traditionally has authority to control conduct that occurs within its borders. This is a central postulate of sovereignty, and the nexus between the state and the conduct is close, obvious, and uncontested. It usually causes few problems, because the question 'does the conduct occurs within the territory?' is usually not difficult to answer. ${ }^{9}$ However, as the illustrative case presented above suggests, in competition law it is not always easy to determine whether an action is conducted within the territory of a particular state or not. Consequently, in the field of competition law, a particular principle that expands the traditional jurisdictional principle based on territory then developed. This principle was first applied by the United States after the World War II ended, and is widely known as the "effects principle" or "effects doctrine". ${ }^{10}$

By definition, "effects doctrine" is a principle by which a state is recognized to have jurisdiction over actions conducted beyond its territorial border that bring damaging effects in the territory of that state. As the term indicates, the most important concept in this doctrine that provides justification for implementing competition law over conducts taken by foreign undertakings located in foreign territories is the effect brought by such conducts on the competition condition in a particular country. In the United States, the embryonic form of this doctrine could be found in the Alcoa Case (United States v. Alcoa) concerning the extra-territorial implementation of US antitrust law. The court in that case delivered its consideration: 'it is settled law ... that any state may impose liabilities, even upon persons not within its allegiance, for conduct outside its borders that has consequences within its borders which the state reprehends...' and that 'the Court found the Sherman Act applicable to foreign conduct because such conduct was 'intended to affect imports [into the US] and did affect them.'11

David J. Gerber, Global Competition - Law, Market and Globalization, Oxford: Oxford University Press, 2010, p. 3.

$8 \quad$ Crystal R. Whitterrick, "Regulation of Competition in the Canada/U.S. Context - Extraterritorial Reach of U.S. Antitrust Law - A Canadian Perspective”, Canada-United States Law Journal, Vol. 24, Issue 1, 1998, p. 299.

David J. Gerber, Op.cit., p. 59.

Ibid., p. 60.

Ibid., p. 64. 
The application of this doctrine by the United States was not without challenge. During the 1950s - 1960s, protests from other countries are directed to this jurisdictional claim based on effects principle. Governments and scholars in Europe and elsewhere argued that the principle had never been accepted as a basis for jurisdiction under international law and, therefore, that the United States was violating international law. However, objections to this principle subsequently subsided, and an increasing number of states started recognizing that under modern economic conditions it was useful to have jurisdictional authority over conduct outside their territory that brought deteriorating effects to domestic competition. ${ }^{12}$ Nowadays, United States authorities are aggressively enforcing United States antitrust laws against conduct occurring entirely outside the United States. Referring to a United States Department of Justice report, Knebel wrote that about 90 percent of fines for criminal violations of United States antitrust laws since 1999 have been levied against non-United States defendants for conduct occurring outside the United States. About sixty percent of fines in excess of $\$ 10$ million have been levied against Asian companies. ${ }^{13}$

In the European Union, to some extent, effects doctrine is also accepted. This was reflected in the Wood Pulp case examined and decided by the European Court of Justice (ECJ) in the 1980-s. This case started when fines were imposed on some wood pulp producers and associations domiciled outside of the European Community (EC) territory after the EC Commission decided that they had violated Article 85 of the EC Treaty, among others by concerting their selling price in the EC market. They objected to the decision of the Commission and brought an action against the decision of the Commission before the ECJ. One of the central arguments of the applicants is that the Commission's action of applying Article 85 would be contrary to public international law which precludes any claim by the EC to regulate conduct restricting competition adopted outside the territory of the EC merely by reason of the economic repercussions which that conduct produces within the EC. ${ }^{14}$

Responding to this objection, the ECJ delivered the opinion "that an infringement of Article 85, such as the conclusion of an agreement which has had the effect of restricting competition within the common market, consists of conduct made up of two elements, the formation of the concerted practice and the implementation thereof. The Court then concluded that if the implementation of prohibitions laid down under competition law were made to depend on the place where the concerted practice was formed, the result would obviously be to give undertakings an easy means of evading those prohibitions, and thus the decisive factor is therefore the place where it is implemented. ${ }^{15}$

12 Ibid., pp. 66-67.

13 Donald E. Knebel, "Extraterritorial application of U.S. antitrust laws: principles and responses", Jindal Global Law Review, Vol. 8, No. 2, 2017, p. 182.

14 European Court Reports, A. Ahlström Osakeyhtiö and Others v. Commission of the European Communities, Judgment of the Court, Case Number 89/85, 27 September 1988.

15 Ibid., para 16. 
Unlike the effect's doctrine implemented by the US courts that focus more on the substantial effects of certain conducts to domestic competition, to a certain degree the European version of effects doctrine seems to rely more on the place where an agreement or decision on a certain concerted action was implemented ('implementation' doctrine). ${ }^{16}$ However, in both jurisdictions, the implementation of competition law to foreign business actors beyond the state's border is a possibility.

The doctrine concerning extra-territorial implementation of competition law has been adopted by more and more countries to anticipate the developing global competition. Among the ASEAN members, this doctrine is adopted by Singapore, particularly with regard to prohibited merger. As in any other jurisdiction, Singapore prohibits certain merger with anticompetitive effects. ${ }^{17}$ It is explained further in the following paragraph that the prohibition "applies so long as the substantial lessening of competition is within a market in Singapore". ${ }^{18}$ Elucidation of Section 54 then stipulates that the Section 54 Prohibition may apply even where the merger takes place outside of Singapore, or where any merger party is outside Singapore, so long as the substantial lessening of competition is within any market in Singapore. This rule clearly reflects that Singapore adopts the "effects doctrine" in prohibiting anticompetitive mergers.

The other ASEAN member that has also introduced the effects doctrine in its competition law is the Philippines. Section 3 of the Philippine Competition Law specifies that the law shall be "applicable to international trade having direct, substantial, and reasonably foreseeable effects in trade, industry, or commerce in the Republic of the Philippines, including those that result from acts done outside the Republic of the Philippines."19

To sum up this part, it is important to note that the globalization as well as the establishment of regional economic integration such as the one pursued by the ASEAN Economic Community requires states to approach competition issues from different angle, departing from the traditional jurisdictional principle deeply based on territorial connections. In a more globalized economy, competition will inevitably involve foreign enterprises. Interrelatedness and interdependency among different undertakings from different countries in the production and distribution of commodities will unquestionably increase. Consequently, the interconnectivity in production and distribution networks that goes beyond national borders will allow the emergence of situations in which business actions taken by foreign enterprises in foreign territory may bring effects to domestic competition. To cope with the dimensions of globalized competition as a consequence of AEC, it is a need for Indonesia to clearly adopt the "effects doctrine" in the Indonesian Competition Law.

\footnotetext{
Caron Beaton-Wells and Brent Fisse, Australian Cartel Regulation - Law, Policy and Practice in an International Context, Cambridge: Cambridge University Press, 2011, p. 18.

Section 54(1) of the Singapore Competition Act 2004.

Ibid., para 2.

Section 3 of the Republic Act No. 10667 (Philippine Competition Act 2014).
} 


\section{Conformity of Indonesian Competition Law with the Principles of ASEAN Competition Guidelines}

As noted earlier, the establishment of the AEC has in turn brought impacts on the realization of the ASEAN single market, which will be characterized by an increasingly competitive phenomenon among business actors from different countries within the ASEAN region. In such a framework, it is important to examine whether the Indonesian Competition Law is in conformity with the principles of competition policy contained in the ASEAN Competition Guidelines. This section specifically contains the results of the study of the issue, by adopting the ASEAN business competition principles as the benchmark.

When confronted with the principles withdrawn from the ASEAN Competition Guidelines, it can be submitted that in general the Indonesian Competition Law has a substantial degree of conformity. As required by the ASEAN Competition Guidelines, the Indonesian Competition Law is in principle a general instrument governing all business sectors, other than those explicitly excluded by laws and regulations. The existence of this principle in the Indonesian Competition Law is implicitly evident from the provisions of Article 51 stating "the production and or distribution of goods and or services that affect the livelihood of the public and the production branches that are important to the state shall be regulated by law." Implicitly this provision suggests that the production and distribution of goods and services not included in the category of Article 52 are otherwise subject to the Indonesian Competition Law.

According to the Indonesian Competition Law, State-Owned Enterprises are also included in the category of business actors that should be subject to the provisions of the competition law. This principle is evident from the definition of business actors in Article 1(e), which indicates that State-Owned Enterprises are included as business actors defined by the Indonesian Competition Law. This principle is also in conformity with the ASEAN competition principles stipulating that competition policy should also apply to Government-Owned Enterprises, as long as there is no explicit exception by law.

According to the ASEAN Competition Guidelines, competition policy shall prohibit vertical as well as horizontal agreements between business actors that are preventive, distorting, or limiting business competition. Similarly, under Indonesian Competition Law, horizontal or vertical agreements that prevent, distort, or restrict business competition are regulated by considering the variations of agreements that may be agreed upon by business actors. The regulation of prohibited agreements is provided in Chapter III (Article 4 through Article 16) of the Indonesian Competition Law.

In the ASEAN Competition Guidelines, the prohibition of actions that undoubtedly bring negative impacts on business competition is called "hardcore restriction". It is also contained in several articles of the Indonesian Competition Law. They are, among others, in Article 5 paragraph (1), which prohibits price fixing; Article 6, 
which prohibits price discrimination; Article 10, which prohibits boycott; Article 15, which prohibits exclusive dealing and conditional exclusive dealing; Article 25, which prohibits abuse of dominant position; and Article 27, which prohibits crossownership of undertakings.

Agreements or actions, which do not necessarily have anticompetitive or unfair nature, are treated with the standard "rule of reason" approach as defined in the ASEAN Competition Guidelines. Unlike prohibited actions or agreements that fall under the "hardcore restriction" category, there are agreements or actions that do not necessarily prevent competition. ${ }^{20}$ Against such agreements or actions, the Indonesian Competition Law implements cautious treatment. Agreements or actions suspected to have a negative impact on competition will be further assessed, and will only be established violating the law once, it is determined that there is a negative impact on business competition. This is what in business competition law is known as "rule of reason approach". An example of agreement that is treated with a "rule of reason approach" is a merger between two or more companies. Merger itself in many ways can bring a positive impact on business actors, so it is not necessarily prohibited. A merger will be regarded as violating the business competition provisions when the action has a negative impact on business competition. This approach is also one of the principles contained in the ASEAN Competition Guidelines and has been accommodated in the Indonesia Competition Law.

Mergers seem to be receiving great attention in the ASEAN Competition Guidelines which contains the principle that a review mechanism should be provided so that the pre-arranged merger does not violate the provisions of competition law. This principle shows that competition law is not intended to prevent mergers, but to ensure that they do not violate the competition law. Indonesian Competition Law is also familiar with the procedure of pre-merger notification as referred to in the ASEAN Competition Guidelines. Article 28(1) of Indonesian Competition Law stipulates that entrepreneurs are prohibited from conducting merger or dissolving companies that might cause monopolistic practices and/or unfair business competition. Detailed requirements and procedures concerning merger is contained in the Regulation of the Business Competition Supervisory Commission Number 13/2010 as amended by Commission Regulation Number 2/2013.

In addition to mergers, actions or agreements that are also governed by the "rule of reason approach" in the Indonesian Competition Law include below market price-fixing agreements (Article 7), regional distribution agreements (Article 9), cartels (Article 11), trust (Article 12), monopolies (Article 17), market control (Article 19), unfair pricing (Article 21), and conspiracy (Article 22).

Despite most of the business competition principles contained in the ASEAN Competition Guidelines are already accommodated in Indonesian Competition Law, there are, in fact, three principles that have not been clearly reflected in it. They are the principle that extend the application of competition law to include individuals

20 Douglas Broder, US Antitrust Law and Enforcement, New York: Oxford University Press Inc., 2010, p. 16. 
with certain qualifications, the principle concerning the positions of business association decisions in the context of business competition law, and the principle relating to concerted action.

Concerning the subjective scope of the business competition law, the ASEAN Competition Guidelines requires that the reach of business competition law be extended to include individuals authorizing, engaging or facilitating practices that are prohibited by the competition policy. This principle is similar to the concept of "accomplices" in criminal law, which is intended to provide a legal basis for applying the law to those who accompany or assist the violation of the law.

In the current Indonesian Competition Law, there is no clear provision applicable to individuals who authorizes, engages, or facilitates the violation of competition law. Under Indonesian Competition Law, individuals simply are referred to in the category of business actors who can violate business competition law as well as business entities, as stipulated in Article 1(e). This makes the parties that can be covered by competition law is limited to business actors, either individuals or other business entities, which are directly involved as violators of competition law. In fact, in practice there are situations where violations of competition law involve the role of non-business actors. Such situations can, for example, be found in a bid rigging that may involve individual auction organizers as a party that makes bid rigging possible. So far, Indonesian Competition Law does not contain clear norms to regulate individuals who participate in violation of competition law. At the most, individuals who take part in competition law violations could be reached only if the violations are brought into the domain of criminal justice system. Under the Indonesian Competition Law, violations of competition law will likely be treated as criminal actions in a particular situation, where the violator intentionally refuses to carry out the decision of the Business Competition Supervisory Commission, following an examination by the Commission. In such case, according to Article 44 of the Indonesian Competition Law, the Commission shall hand over the decision to the criminal investigators for pursuant to the existing law. It simply means that if the violators of competition law accept the Commission's decision and subsequently carry out the rulings, criminal procedure will not be commenced.

In addition, a legal issue has to be clarified concerning the limit of the authority of the Business Competition Supervisory Commission in imposing administrative sanctions. The problem is that there is no clear indication to whether the Commission may only examine business actors in the strictest meaning as defined in Article 1, or it is possible for the Commission to bring legal action against any person as well (either natural and legal person, private and public) that violate the competition law. This issue is evident in Gamma Ray Container Scanner case decided by the Commission in 2005. This case began when the Commission received reports that there were unfair practices in the procurement of Gamma Ray Container Scanner by Batam Authority Agency (BAA). Based on the report, the Commission then performed examination and ultimately found that the business actor involved, a private company named 
PT Mitrabuana Widyasakti (as the Second Respondent) and the Procurement Committee of the BAA (as the First Respondent) were guilty of violating Article 22 of the Indonesian Competition Law which prohibits tender conspiracy. ${ }^{21}$ Considering that the Procurement Committee of the BAA was a public ad hoc entity, the decision of the Business Competition Supervisory Commission was criticized.

The absence of a clear-cut definition concerning who can be the subject of scrutiny of the Commission has in fact left the question, as to whether the Indonesian Competition Law is extended to include individuals, unanswered. Therefore, the principle on who can be the subject of examination of the Commission must be clarified to accommodate the principle of individual extension of competition law as put forward by the ASEAN Competition Guidelines.

The second matter that have not been clearly regulated is the pronouncement in the competition law that decisions made by trade associations must also be in harmony with the legal norms of business competition. From a legal perspective, business association decisions hardly can be categorized as agreements and when those decisions are contrary to the norms of business competition, it is difficult to categorize them as prohibited agreements. Therefore, business association decisions are often located in gray areas that have not been covered explicitly by the provisions of competition law.

The existence of business association along with the pros and cons from competition law perspective was debated intensely by the Organization for Economic Cooperation and Development (OECD). In 2007 a report, OECD clearly portrayed business or trade association as benefiting competition in one aspect while threatening fair competition in another aspect. It is widely acknowledged that business associations may play a role as forums for promoting the efficient functioning of the market. However, they could also be forums where competitors discuss and arrange business actions for the sake of common interest of the members of association, in a way that may harm fair competition principles. ${ }^{22}$

Under current Indonesian Competition Law, any violation of competition law performed by members of trade association as a result of a decision of trade associations are dealt with in a similar way as any other violation. The role of trade associations in encouraging violation of competition law by way of their decisions are so far deemed irrelevant. Considering the trade associations may be beneficial or harmful to fair competition, Indonesian Competition Law need to insert rules that clearly place trade associations within the reach of competition law.

A similar problem exists in the third matter, which has not been covered explicitly by Indonesian Competition Law, namely concerted action. In practice, it is quite possible that some business actors take certain actions in such a way as to achieve certain objectives that may be contrary to the competition law. These actions can

21 Decision of the Business Competition Supervisory Commission, Case Number 19/KPPU-L/2005.

22 OECD Policy Roundtables on Trade Association, DAF/COMP(2007)45, http://www.oecd.org/regreform/ sectors/41646059.pdf, accessed on May 2018. 
be based on obvious agreements, but can also be done by individual business actors by implicit understanding. Corresponding acts among some business actors based on this implicit understanding are referred commonly to as concerted action. The position of concerted action, though often mentioned in recent cartel cases, has not been regulated explicitly in Indonesian Competition Law.

\section{E. Conclusions}

After several points are stated in the previous sections, this study can be concluded in two points as follows.

1. The Indonesian competition law inappropriately do not contain adequate provisions to anticipate and regulate foreign business actors, especially from ASEAN members, who step into the domain of Indonesian business competition in the era of AEC. There is a lack in terms of rules to deal with extra-territorial competition issues.

2. To a substantial degree, the Indonesian competition law is compatible with the ASEAN regional business competition principles set forth in the ASEAN Competition Guidelines. However, three issues need to be developed: the application of competition law to include individuals with certain qualifications, clarification concerning the positions of business association decisions in the context of business competition law, and formulation of the principle relating to concerted action, which has developed in the Commission's case law.

Based on the discussion concerning the two issues mentioned at the beginning of this paper, it can be concluded that Indonesian Competition Law still relies heavily on the principle of territoriality in the application of its norms. Under this principle, the main criterion of the law implementation is the place where the business actor is established and located, or the territory in which the entity operates. The establishment of ASEAN single market through AEC will make Indonesia exposed to the possibility of interaction with foreign business actors outside Indonesia. It may impair the condition of business competition in Indonesian domestic market. In these extra-territorial situations, the application of territorial principles is not sufficient. If the provision concerning the criteria of business actors contained in Article 1 (e) of the Indonesian Competition Law is not revised, the Indonesian competition authority will find it difficult to enforce competition law norms against business actors outside Indonesia that perform actions harming Indonesia's interests. It should always be considered that the business actors outside of Indonesia might harm Indonesia's domestic competition. It tends to increase with the application of ASEAN Economic Community. Therefore, the territorial principle contained in Article 1(e) of the Competition Law should be reviewed for adopting the principle of extra-territoriality. It will enable the Indonesian competition authority to implement Indonesian Competition Law to business actors outside Indonesia who harm the business competition in Indonesia. For this purpose, the "effects doctrine" that develops in the practice of competition in other countries can be used as the basis 
for applying the extra-territorial principle. Therefore, the Indonesian Competition Law must be considered to extend the range of its implementation through the extra-territorial principle based on the "effects doctrine" justifying the application of national law to any business actor that causes the disruption of fair business competition conditions at the domestic level and capable of violating national competition and antitrust laws. ${ }^{23}$

In addition, despite Indonesia's business competition law has a substantial degree of compatibility with the ASEAN competition policy principles, there are three principles that have not been adequately addressed in Indonesian Competition Law. They are (1) the principle related to the extension of the competition law to include individuals who indirectly take part in the violation of competition law; (2) the principle of extending the Indonesian competition law norms to include business association decisions that have the potential to violate competition law; and (3) the principle that concerted action that may disrupt competition be more strictly regulated.

Based on the discussion, it appears that reform of Indonesian Competition Law should be conducted to anticipate all shortcomings. Therefore, the Indonesian Competition Law is able to respond to the inevitably more dynamic business competition emerging as a consequence of the establishment of AEC. To sum up, the following issues should be the focus of reform of Indonesian Competition Law in the wake of AEC implementation: (1) adoption of the 'effects principle' to deal with extra-territorial competition issues; (2) extension of the application of competition law to include individuals with certain qualifications; (3) clarification concerning the positions of business association decisions in the context of business competition law; and (4) formulation of the principle relating to concerted action, which has developed in the Commission's case law.

\section{References}

\section{Books}

ASEAN, ASEAN Regional Guidelines on Competition Policy, ASEAN Secretariat, Jakarta, 2010.

--------, Celebrating ASEAN: 50 Years of Evolution and Progress, ASEAN Secretariat, Jakarta, 2017.

Beaton-Wells, Caron and Brent Fisse, Australian Cartel Regulation - Law, Policy and Practice in an International Context, Cambridge University Press, Cambridge, 2011.

Broder, Douglas, US Antitrust Law and Enforcement, Oxford University Press Inc., New York, 2010.

Dabbah, Maher M., The Internationalization of Antitrust Policy, Cambridge University Press, Cambridge, 2003.

23 Jörg Philipp Terhechte, International Competition Enforcement Law Between Cooperation and Convergence, Heidelberg: Springer, 2011, p. 42. 
Gerber, David J., Global Competition - Law, Market and Globalization, Oxford University Press, Oxford, 2010.

Terhechte, Jörg Philipp, International Competition Enforcement Law Between Cooperation and Convergence, Springer, Heidelberg, 2011.

Wish, Richard and David Bailey, Competition Law, Oxford University Press, Oxford, 2012.

Zimmer, Daniel (ed.), The Goals of Competition Law, Edward Elgar Publishing Limited, Cheltenham, 2012.

\section{Other Documents}

Whitterrick, Crystal R., "Regulation of Competition in the Canada/U.S. Context Extraterritorial Reach of U.S. Antitrust Law - A Canadian Perspective", CanadaUnited States Law Journal, Vol. 24, Issue 1, 1998.

Knebel, Donald E., "Extraterritorial application of U.S. antitrust laws: principles and responses", Jindal Global Law Review, Vol. 8, No. 2, 2017.

OECD Policy Roundtables on Trade Association, DAF/COMP (2007)45, http://www. oecd.org/regreform/sectors/41646059.pdf, accessed on May 2018.

\section{Legal Documents}

Law Number 5 of 1999 on Prohibition of Monopoly and Unfair Business Competition.

Philippine Competition Act 2004 (Republic Act No. 10667).

Singapore Competition Act 2004.

European Court Reports, A. Ahlström Osakeyhtiö and Others v. Commission of the European Communities, Judgment of the Court, Case Number 89/85, 27 September 1988.

Decision of the Business Competition Supervisory Commission, Case Number 19/ KPPU-L/2005. 